\title{
Excessive meat consumption in Brazil: diet quality and environmental impacts
}

\author{
Aline Martins de Carvalho', Chester Luiz Galvão César ${ }^{2}$, Regina Mara Fisberg ${ }^{1}$ and \\ Dirce Maria Lobo Marchioni ${ }^{1, *}$ \\ 'Department of Nutrition, School of Public Health, University of São Paulo, Av. Dr. Arnaldo 715, São Paulo, \\ CEP 01246-904, SP, Brazil: '2Department of Epidemiology, School of Public Health, University of São Paulo, \\ São Paulo, SP, Brazil
}

Submitted 27 October 2011: Final revision received 14 June 2012: Accepted 3 July 2012: First published online 16 August 2012

\begin{abstract}
Objective: To evaluate red and processed meat intake, and the impact meat consumption has on diet quality and the environment.

Design: A large cross-sectional health survey performed in São Paulo, Brazil.

Setting: Diet was assessed by two $24 \mathrm{~h}$ dietary recalls. Usual intakes were calculated using the Multiple Source Method. The World Cancer Research Fund recommendation of an average of $71.4 \mathrm{~g} / \mathrm{d}$ was used as the cut-off point to estimate excessive red and processed meat consumption. To investigate the relationship between meat consumption and diet quality we used the Brazilian Healthy Eating Index Revised. The environmental impact was analysed according to estimates of $\mathrm{CO}_{2}$ equivalent emissions from meat consumption.

Subjects: Brazilians ( $n$ 1677) aged 19 years and older were studied.

Results: The mean red and processed meat intake was $138 \mathrm{~g} / \mathrm{d}$ for men and $81 \mathrm{~g} / \mathrm{d}$ for women. About $81 \%$ of men and $58 \%$ of women consumed more meat than recommended. Diet quality was inversely associated with excessive meat intake in men. In Brazil alone, greenhouse gas emissions from meat consumption, in 2003, were estimated at approximately 18071988 tonnes of $\mathrm{CO}_{2}$ equivalents, representing about $4 \%$ of the total $\mathrm{CO}_{2}$ emitted by agriculture.

Conclusions: The excessive meat intake, associated with poorer diet quality observed, support initiatives and policies advising to reduce red and processed meat intake to within the recommended amounts, as part of a healthy and environmentally sustainable diet.
\end{abstract}

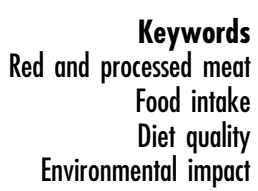

Meat is an important food item for human nutrition because it contains 20 to $40 \%$ protein, and also minerals such as iron, zinc and selenium, and vitamins $\mathrm{B}_{6}$ and $\mathrm{B}_{12}{ }^{(1)}$. The unsaturated and the conjugated fatty acids from meat may help prevent $\mathrm{CVD}^{(2)}$. However, excessive meat consumption leads to high intakes saturated fat, cholesterol, potentially carcinogenic substances such as heterocyclic amines and polycyclic aromatic hydrocarbons $^{(3)}$ formed during the cooking process, and sodium and nitrite that are added in processed meats. Therefore excessive meat consumption has been linked to chronic diseases ${ }^{(4)}$ such as CVD, diabetes ${ }^{(5)}$, colorectal cancer $^{(3)}$, weight gain and stroke ${ }^{(6-8)}$

Excessive meat consumption has been negatively associated with diet quality in some countries ${ }^{(6,9)}$. In the USA, meat consumption has been a public health concern since late 1950s, when the American Heart Association released recommendations to prevent $\mathrm{CVD}^{(4)}$. Today, the World Cancer Research Fund (WCRF) recommends limited consumption ( $500 \mathrm{~g} /$ week) of cooked red meats (beef and pork) and processed meats (cured, salted, smoked or containing chemical preservatives) for cancer prevention $^{(3)}$. The Brazilian Ministry of Health recommends one serving of meat daily $(100 \mathrm{~g} / \mathrm{d})$ for a healthy diet $^{(1)}$, but there are few studies evaluating meat intake in Brazil.

Livestock production already takes up $30 \%$ of the world's useable land area and causes major impacts on the environment due to: deforestation for livestock grazing; emission of greenhouse gases by animals; water pollution by discharge of organic matter, pathogens, drug residues and antibiotics into lakes, rivers and seas; and loss of biodiversity ${ }^{(10)}$. Cattle-ranching is an important economic activity in Brazil. The country is one of the world's largest beef exporters ${ }^{(10)}$. However, this sector of the economy is the second-largest emitter of greenhouse gases in Brazil, mainly due to enteric fermentation by ruminant herbivores (one of the greatest sources of methane emissions in the country) and also due to handling of animal wastes ${ }^{(11)}$. 
Considering the possible deleterious effects of excessive meat consumption on human health and the environment, monitoring the production and consumption of meat is important to promoting healthy eating policies. The aim of the present study was to evaluate red and processed meat intake and also to assess the impact of this consumption on diet quality and the environment.

\section{Experimental methods}

\section{Study design and participants}

The data come from a cross-sectional population-based survey entitled 'Health Survey for São Paulo', conducted in 2003 (ISA-Capital 2003) $^{(12)}$. A two-stage cluster sampling was used: census tracts and households. Census tracts were grouped into three strata based on the percentage of household heads with higher education. More details on sampling are available in Castro et $a l^{(13)}$. In the present study, the final sample comprised 1677 individuals (both males and females): 847 adults and 830 elderly people.

Information about health, food intake and life conditions was collected in a representative sample of residents of the city of São Paulo, Brazil, by a structured questionnaire applied at participants' homes. This questionnaire concerning demographic (age, gender), socio-economic (family income, education level of the household head) and lifestyle characteristics (smoking, alcohol consumption) was administered by trained interviewers at the participants' homes.

A follow-up study was completed in 2007 with a second household dietary survey. The final sample comprised 486 individuals (both males and females): 195 adults and 291 elderly people. Loss in the sample was due absence in the house after three attempts, refusal and change of address.

The project was approved by the Ethics Committee of the School of Public Health, University of São Paulo.

\section{Assessment of dietary intake}

Dietary assessment consisted of two $24 \mathrm{~h}$ dietary recalls (24HR) adapted from Thompson and Byers ${ }^{(14)}$. Interviewers were trained on using standard forms for administering the $24 \mathrm{HR}$ and received a manual explaining how to fill it out, thus standardizing data collection. Data were collected in 2003 and in 2007 at participants' households, every day of the month for the period of a year.

The household measures reported were converted into grams and millilitres, according to Pinheiro et al. ${ }^{(15)}$ and Fisberg and Villar ${ }^{(16)}$. Recipes were broken down into ingredients to estimate the amount of meat in each preparation.

Data from the $24 \mathrm{HR}$ were entered into the Nutrition Data System for Research program version 5.0 (2007) developed by the Nutrition Coordinating Center, University of Minnesota (Minneapolis, MN, USA) and were converted to energy and nutrients (total fat, saturated fat, dietary fibre and vitamin C).

\section{Definition of red and processed meat intake}

The variable 'red and processed meat' was calculated using the sum of red meat (beef and pork) and processed meat (cured, salted, smoked or containing chemical preservatives).

The Multiple Source Method (MSM), a statistical modelling technique, was used to estimate the usual dietary intake of red and processed meat. This technique uses two $24 \mathrm{HR}$ and a probability of consumption ${ }^{(17,18)}$. The MSM calculates dietary intake for individuals first and then constructs the population distribution based on the individual data. Age group and date of interview were included as covariates of the model. All participants were considered daily meat consumers in MSM, because meat, especially red and processed meat, is consumed by almost all of São Paulo's population according to previous data ${ }^{(19,20)}$.

The WCRF maximum recommended intake of red and processed meat of $500 \mathrm{~g} /$ week, corresponding to an average of $71.4 \mathrm{~g} / \mathrm{d}$, was the cut-off point to estimate excessive red and processed meat intake ${ }^{(3)}$.

\section{Diet quality}

To investigate the relationship between meat consumption and diet quality, we used the Brazilian Healthy Eating Index Revised (BHEI-R) ${ }^{(21)}$. The BHEI-R evaluates a combination of different types of foods, nutrients and other components of the diet according to current dietary recommendations, especially the Brazilian Dietary Guidelines ${ }^{(1)}$. The BHEI-R is similar to the Healthy Eating Index- $2005^{(22)}$ and comprises twelve components: nine are food groups expressed in terms of energy density (per $4174 \mathrm{~kJ} / 1000 \mathrm{kcal}$ : 'total fruits', 'whole fruits', 'total vegetables', 'dark green and orange vegetables and legumes', 'total grains', 'whole grains', 'milk and dairy', 'meat, eggs and legumes', 'oils'); two are nutrients (sodium and saturated fat); and the other is energy from solid fat, added sugars and alcohol (SoFAA). The maximum score for the first six components is 5 , for the next five components is 10 and for the last component is 20. Intermediate scores are calculated proportionately. Thus, the final score of the BHEI-R ranges from zero to 100. The following components were analysed: SoFAA, total vegetables, whole fruits, whole grains, and milk and dairy.

\section{Environmental impact}

To evaluate the environmental impact caused by meat consumption, we estimated the amount of red and processed meat consumed by the population of São Paulo in 2003 (10615844 people) ${ }^{(23)}$. Then, we estimated greenhouse gas emissions from total meat consumption, knowing that the production of $1 \mathrm{~kg}$ of Brazilian beef generates about $44 \mathrm{~kg}$ of $\mathrm{CO}_{2}$ equivalents ${ }^{(24)}$. There is no available information on the carbon footprint of pig and processed meat production in Brazil, so we used red and processed meat intake from beef production as proxy. 


\section{Statistical analyses}

Mean values, 95\% confidence intervals and proportions of participants who consumed red and processed meat were calculated considering the predicted usual intake distribution by MSM, adjusted by age group and year of interview, separated by sex.

Differences between means and proportions were analysed using the lincom test, which calculates point estimates using the $t$ statistic and considers the weights from complex samples ${ }^{(25)}$.

The association between energy intake, nutrient intakes and selected BHEI-R scores according to categories of red and processed meat consumption (moderate intake; high intake) was investigated by ANOVA.

For all analyses, the STATA statistical software package version 10 (2007) was used and $P<0.05$ was considered statistically significant.

\section{Results}

Daily per capita consumption of red and processed meat was $106 \mathrm{~g} ; 138 \mathrm{~g}$ for men and $81 \mathrm{~g}$ for women. Daily consumption of pork was $8 \mathrm{~g}$, of beef was $73 \mathrm{~g}$ and of processed meat was $25 \mathrm{~g}$ (data not shown).

The average daily red and processed meat intake according to socio-economic, demographic and lifestyle variables is shown in Table 1.
The proportion of participants with high red and processed meat intake was $81 \%$ of men and $58 \%$ of women (Table 2). There were no significant differences according to the characteristics analysed, except that adult females had a higher proportion of high consumers than elderly women $(P<0 \cdot 05$; Table 2$)$.

We also found that those who had high red and processed meat intake had higher intakes of energy, total and saturated fat, in both sexes (all $P<0 \cdot 01$ ). For men and women who consumed meat in excess, energy intake was respectively 1.4 times and 1.3 times higher; total fat intake was respectively 1.7 times and 1.5 times higher; and saturated fat intake was respectively $2 \cdot 0$ times and 1.6 times higher, compared with those who had moderate intake. Consumption of vitamin $\mathrm{C}$ and dietary fibre were not different among the groups (Table 3).

When we evaluated the BHEI-R score, it was significantly lower $(P<0 \cdot 01)$ among males who had high intake of red and processed meat; that is, diet quality was inversely associated with excessive meat consumption among men (Table 3).

Scoring for SoFAA was significantly lower in men $(P<0.01)$ and women $(P<0.05)$ with high red and processed meat intake, showing that these individuals consumed more solid fat, added sugars and alcohol than the other participants. High consumption of red and processed meat was also negatively related to

Table 1 Usual red and processed meat intake ( $\mathrm{g} / \mathrm{d})$ according to sex and socio-economic variables: Brazilian adults ( $n$ 1677) aged $\geq 19$ years, São Paulo, 2003

\begin{tabular}{|c|c|c|c|c|c|c|}
\hline & \multicolumn{3}{|c|}{ Males } & \multicolumn{3}{|c|}{ Females } \\
\hline & $n$ & Mean & $95 \% \mathrm{Cl}$ & $n$ & Mean & $95 \% \mathrm{Cl}$ \\
\hline \multicolumn{7}{|l|}{ Age group } \\
\hline Adult & 347 & 143 & 138,148 & 399 & 84 & 79,88 \\
\hline $\begin{array}{l}\text { Elderly } \\
P^{\star}\end{array}$ & 395 & $\begin{array}{r}105 \\
<0 \cdot 05\end{array}$ & 101,109 & 421 & $\begin{array}{r}64 \\
<0.05\end{array}$ & 60,68 \\
\hline \multicolumn{7}{|l|}{ Education of household head } \\
\hline$\leq 7$ years & 436 & 135 & 128,141 & 490 & 79 & 74,85 \\
\hline$\geq 8$ years & 298 & 142 & 135,148 & 317 & 83 & 77,88 \\
\hline$P^{*}$ & & $0 \cdot 14$ & & & 0.42 & \\
\hline \multicolumn{7}{|l|}{ Family income per capita } \\
\hline Low income & 202 & 131 & 122,139 & 299 & 82 & 76,88 \\
\hline Middle income & 226 & 141 & 133,150 & 234 & 83 & 73,92 \\
\hline High income & 254 & 139 & 132,146 & 226 & 80 & 74,86 \\
\hline$P^{\star}$ & & $0 \cdot 16$ & & & $0 \cdot 81$ & \\
\hline \multicolumn{7}{|l|}{ Smoking } \\
\hline Non-smoker & 331 & 138 & 131,145 & 572 & 78 & 74,82 \\
\hline Smoker and ex & 390 & 136 & 130,142 & 226 & 87 & 78,95 \\
\hline $\begin{array}{l}P^{*} \\
\text { Alcohol consumption }\end{array}$ & \multicolumn{5}{|c|}{ Alcohol consumption } & \\
\hline Did not drink for 1 year & 299 & 133 & 127,140 & 542 & 79 & 74,84 \\
\hline Drinks at least twice a month & 419 & 139 & 132,145 & 251 & 85 & 79,91 \\
\hline$P^{*}$ & & 0.26 & & & 0.14 & \\
\hline \multicolumn{7}{|l|}{ Race } \\
\hline White & 482 & 135 & 128,141 & 551 & 83 & 78,87 \\
\hline Other & 258 & 143 & 135,150 & 267 & 77 & 71,84 \\
\hline$P^{*}$ & & $0 \cdot 17$ & & & $0 \cdot 19$ & \\
\hline Total & 742 & 138 & 133,142 & 820 & 81 & 77,85 \\
\hline
\end{tabular}

${ }^{*} P$ value for $F$ statistic (lincom test). 
milk and dairy and positively related to total vegetables in women (both $P<0 \cdot 01$ ). Total fruit and whole grains did not show statistical difference among groups (Table 4).

The estimated amount of red and processed meat consumed by the population of São Paulo, in 2003, was about 410727 tonnes. The production of this amount of meat released 18071988 tonnes of $\mathrm{CO}_{2}$ equivalents into the environment, which represents $4 \cdot 1 \%$ of the total $\mathrm{CO}_{2}$ emitted by agriculture in Brazil in 2003.

Table 2 Proportion (\%) of individuals with high daily red and processed meat intake according to sex and socio-economic variables: Brazilian adults $(n$ 1677) aged $\geq 19$ years, São Paulo, 2003

\begin{tabular}{lcc}
\hline & Males (\%) & Females (\%) \\
\hline Age group & & \\
Adult & 82 & 61 \\
Elderly & 77 & 41 \\
$P^{\star}$ & 0.08 & $<0.05$ \\
Education of household head & & \\
$\leq 7$ years & 79 & 58 \\
$\geq 8$ years & 83 & 58 \\
$P^{*}$ & 0.46 & 0.99 \\
Family income per capita & & \\
Low income & 73 & 57 \\
Middle income & 85 & 63 \\
High income & 84 & 56 \\
$P^{\star}$ & 0.12 & 0.66 \\
Smoking & & \\
Non-smoker & 80 & 55 \\
Smoker and ex & 81 & 65 \\
$P^{*}$ & 0.72 & 0.06 \\
Alcohol consumption & & \\
Did not drink for 1 year & 79 & 57 \\
Drinks at least twice a month & 81 & 61 \\
$P^{*}$ & 0.61 & 0.41 \\
Race & & \\
White & 80 & 61 \\
Other & 82 & 53 \\
$P^{*}$ & $0 \cdot 67$ & $0 \cdot 16$ \\
Total & 81 & 58 \\
\hline
\end{tabular}

${ }^{\star} P$ value for $F$ statistic (lincom test).

\section{Discussion}

The present study is one of the few representative surveys that estimate meat consumption in Brazil. The results show that meat is consumed almost universally in the city of São Paulo.

We observed that average meat intake exceeded the maximum intake limit recommended by the $\mathrm{WCRF}^{(3)}$ by 1.9 and $1 \cdot 1$ times for men and women, respectively. Similar results were observed elsewhere. In the UK, daily average consumption of red and processed meat is $78 \mathrm{~g}$ and $47 \mathrm{~g}$ for men and women, respectively; in Ireland, $94 \mathrm{~g}$ for men and $58 \mathrm{~g}$ for women; in Spain, $127 \mathrm{~g}$ for men and $68 \mathrm{~g}$ for women ${ }^{(2)}$; and in the USA, $116 \mathrm{~g}$ for men and $71 \mathrm{~g}$ for women ${ }^{(4)}$. What draws attention in our study is that meat consumption in São Paulo was even greater than in the USA, the world's largest beef consumer ${ }^{(4)}$.

Excessive consumption of red and processed meat is not considered healthy. It is known that processed meat intake of only $50 \mathrm{~g} / \mathrm{d}$ is associated with $42 \%$ increased risk of CVD and 19\% increased risk of diabetes ${ }^{(5)}$, and there is convincing evidence that meat increases the risk of colorectal cancer ${ }^{(3)}$.

In our study, excessive meat intake was related to poor diet quality in men, showing that meat consumption had a negative effect on the diet quality. It was also associated with higher energy intake from fats, added sugars and alcohol, and lower intake of milk and dairy in women. In Ireland, high processed meat consumption was also associated with lower intakes of wholegrain breads, fruits, vegetables and fish, and higher soft drinks consumption, when compared with no or little meat consumption ${ }^{(6)}$. In Japanese women, the ratio of fish to meat intake was positively associated with fruits, vegetables, milk and alcohol intakes, and negatively associated with soft drinks, fat and oil intakes, showing that those who consume less red meat have a healthier dietary pattern ${ }^{(9)}$.

Table 3 Average daily energy and nutrient intakes and diet quality according to level of red and processed meat consumption and sex: Brazilian adults ( $n$ 1677) aged $\geq 19$ years, São Paulo, 2003

\begin{tabular}{|c|c|c|c|c|c|c|c|c|c|}
\hline & \multirow{2}{*}{$\begin{array}{l}\text { Red and processed } \\
\text { meat intake }\end{array}$} & \multicolumn{4}{|c|}{ Males } & \multicolumn{4}{|c|}{ Females } \\
\hline & & $n$ & Mean & $95 \% \mathrm{Cl}$ & $P^{\star}$ & $n$ & Mean & $95 \% \mathrm{Cl}$ & $P^{\star}$ \\
\hline \multirow[t]{2}{*}{ Energy (kJ) } & Moderate & 142 & 7063 & 6368,7761 & & 344 & 5632 & 5176,6088 & $<0.01$ \\
\hline & High & 600 & 9636 & 9255,10012 & $<0.01$ & 476 & 7272 & 6912,7632 & \\
\hline \multirow[t]{2}{*}{ Energy (kcal) } & Moderate & 142 & 1688 & 1522,1855 & & 344 & 1346 & 1237,1455 & \\
\hline & High & 600 & 2303 & 2212,2393 & $<0.01$ & 476 & 1738 & 1652,1824 & $<0.01$ \\
\hline \multirow[t]{2}{*}{ Total fat $(\mathrm{g})$} & Moderate & 142 & $52 \cdot 3$ & $45 \cdot 0,59 \cdot 7$ & & 344 & $46 \cdot 3$ & $41 \cdot 3,51 \cdot 3$ & \\
\hline & High & 600 & $90 \cdot 4$ & $85 \cdot 7,95 \cdot 0$ & $<0.01$ & 476 & $71 \cdot 0$ & $66 \cdot 6,75 \cdot 3$ & $<0.01$ \\
\hline \multirow{2}{*}{ Saturated fat $(\mathrm{g})$} & Moderate & 142 & $14 \cdot 5$ & $12 \cdot 1,16 \cdot 9$ & & 344 & $14 \cdot 1$ & $12 \cdot 2,16 \cdot 0$ & \\
\hline & High & 600 & $28 \cdot 8$ & $27 \cdot 1,30 \cdot 5$ & $<0.01$ & 476 & $23 \cdot 0$ & $21 \cdot 3,24.8$ & $<0.01$ \\
\hline \multirow[t]{2}{*}{ Dietary fibre (g) } & Moderate & 142 & $19 \cdot 2$ & $16 \cdot 6,21 \cdot 7$ & & 344 & $13 \cdot 0$ & $12 \cdot 1,14 \cdot 0$ & \\
\hline & High & 600 & $18 \cdot 5$ & $17 \cdot 5,19 \cdot 6$ & 0.66 & 476 & $13 \cdot 8$ & $12 \cdot 9,14 \cdot 6$ & 0.19 \\
\hline \multirow[t]{2}{*}{ Vitamin C (mg) } & Moderate & 142 & $63 \cdot 0$ & $44 \cdot 1,82 \cdot 0$ & & 344 & $64 \cdot 3$ & $33 \cdot 6,95 \cdot 1$ & \\
\hline & High & 600 & $71 \cdot 1$ & $50 \cdot 8,89 \cdot 4$ & 0.57 & 476 & $59 \cdot 1$ & $49 \cdot 3,68 \cdot 9$ & 0.74 \\
\hline \multirow[t]{2}{*}{ BHEI-R (score) } & Moderate & 142 & $59 \cdot 6$ & $57 \cdot 9,61 \cdot 3$ & & 344 & $57 \cdot 9$ & $56 \cdot 2,59 \cdot 5$ & \\
\hline & High & 600 & $54 \cdot 4$ & $53 \cdot 3,55 \cdot 5$ & $<0.01$ & 476 & $56 \cdot 2$ & $54 \cdot 6,57 \cdot 8$ & 0.15 \\
\hline
\end{tabular}

BHEI-R, Brazilian Healthy Eating Index Revised.

${ }^{*} P$ value for $F$ statistic (lincom test). 
Table 4 BHEI-R components and overall BHEI-R score according to level of red and processed meat intake and sex: Brazilian adults ( $n$ 1677) aged $\geq 19$ years, São Paulo, 2003

\begin{tabular}{|c|c|c|c|c|c|c|c|}
\hline & \multirow{2}{*}{$\begin{array}{l}\text { Red and processed } \\
\text { meat intake }\end{array}$} & \multicolumn{3}{|c|}{ Males } & \multicolumn{3}{|c|}{ Females } \\
\hline & & Mean & $95 \% \mathrm{Cl}$ & $P^{\star}$ & Mean & $95 \% \mathrm{Cl}$ & $P^{*}$ \\
\hline \multirow[t]{2}{*}{ SoFAA $(\max 20)$} & Moderate & $13 \cdot 2$ & $12 \cdot 0,14 \cdot 4$ & & $11 \cdot 0$ & $10 \cdot 2,11 \cdot 8$ & \\
\hline & High & $8 \cdot 8$ & $8 \cdot 0,9 \cdot 6$ & $<0.01$ & $9 \cdot 2$ & $8 \cdot 2,10 \cdot 2$ & $<0.05$ \\
\hline \multirow{2}{*}{ Total vegetables $(\max 5)$} & Moderate & $4 \cdot 1$ & $3 \cdot 8,4 \cdot 4$ & & $3 \cdot 8$ & $3 \cdot 5,4 \cdot 1$ & \\
\hline & High & $4 \cdot 5$ & $4 \cdot 3,4 \cdot 6$ & 0.06 & 4.5 & $4 \cdot 3,4 \cdot 8$ & $<0.01$ \\
\hline \multirow[t]{2}{*}{ Total fruits $(\max 5)$} & Moderate & $1 \cdot 7$ & $1 \cdot 2,2 \cdot 2$ & & 1.9 & $1 \cdot 6,2 \cdot 1$ & \\
\hline & High & $1 \cdot 4$ & $1 \cdot 2,1 \cdot 7$ & $0 \cdot 18$ & $1 \cdot 7$ & $1 \cdot 5,2 \cdot 0$ & 0.51 \\
\hline \multirow[t]{2}{*}{ Whole grains $(\max 5)$} & Moderate & 0.3 & $0.1,0.4$ & & 0.4 & $0.2,0.5$ & \\
\hline & High & 0.3 & $0.2,0.4$ & 0.56 & 0.5 & $0.3,0.6$ & 0.37 \\
\hline \multirow[t]{2}{*}{ Milk and diary $(\max 10)$} & Moderate & $3 \cdot 7$ & $2 \cdot 9,4 \cdot 6$ & & $5 \cdot 2$ & $4 \cdot 6,5 \cdot 8$ & \\
\hline & High & $3 \cdot 2$ & $2 \cdot 9,3 \cdot 7$ & $0 \cdot 3$ & $3 . \overline{9}$ & $3 \cdot 5,4 \cdot 4$ & $<0.01$ \\
\hline \multirow[t]{2}{*}{ BHEI-R (range 0-100) } & Moderate & $59 \cdot 6$ & $57 \cdot 9,61 \cdot 3$ & & $57 \cdot 9$ & $56 \cdot 2,59 \cdot 5$ & \\
\hline & High & $54 \cdot 5$ & $53 \cdot 3,55 \cdot 5$ & $<0.01$ & $56 \cdot 2$ & $54 \cdot 6,57 \cdot 8$ & $0 \cdot 15$ \\
\hline
\end{tabular}

BHEI-R, Brazilian Healthy Eating Index Revised; SoFAA, energy from solid fat, added sugars and alcohol.

${ }^{*} P$ values for $F$ statistic (lincom test).

In the present study, excessive meat consumption was also associated with higher energy, total fat and saturated fat intakes; this might increase the risk of CVD and of being overweight, which are prevalent and high-costing diseases. In Brazil, the prevalence of overweight in adults is high, nearly $50 \%{ }^{(26)}$. In São Paulo, the latest figures released show that $44 \%$ of adults are overweight ${ }^{(27)}$. In an European cohort study of more than 350000 adults, a positive association between meat consumption and weight gain was noticed, even after adjustment for energy, dietary patterns, smoking and $\mathrm{BMI}^{(8)}$.

In addition to these health effects, meat production causes large impacts on the environment due to deforestation for livestock grazing, emission of greenhouse gases by animals, water pollution and biodiversity loss ${ }^{(28)}$. We estimated that production of the amount of meat consumed in São Paulo in 2003 accounted for about $4 \%$ of the total greenhouse gases emitted by Brazilian agriculture that year ${ }^{(29)}$.

If a car travelled between Brazil and Canada $(9673 \mathrm{~km})$, it would emit the same quantity of $\mathrm{CO}_{2}$ as was released to supply the meat intake of one person in one year in São Paulo ${ }^{(30)}$. Greenhouse gas emissions would have been almost $50 \%$ lower if meat consumption had not exceeded the maximum recommended by WCRF $(71 \cdot 4 \mathrm{~g} / \mathrm{d})$ in São Paulo.

Promoting dietary changes towards healthy eating is a challenging task, because the process of food choice is complex and driven by features beyond our knowledge, such as cultural, environmental and economic. Although meat is associated with increased risk of chronic diseases and is an expensive food item with complicated food market distribution logistics, it is highly consumed. On the other hand, intake of fruits and vegetables is very low despite their well-known beneficial effects of consumption $^{(31)}$. This might illustrate how a food item is valued by the population in spite of its nutritional composition ${ }^{(32)}$. This can happen because meat, especially red meat, has cultural value. It is desired by people from different cultures and of varying degrees of economic development ${ }^{(33)}$, making it especially attractive for consumption.

For successfully promoting healthy eating, a multidisciplinary approach needs to be taken. Our results add evidence that public policies should focus on encouraging lower red and processed meat consumption in this population, so intake would be within the recommended range, therefore reducing the risk of chronic diseases and preventing environmental degradation.

\section{Limitations}

The ISA-Capital 2003 is a cross-sectional study in which we cannot determine causality of events, but by using a probability sample and being a population-based study, results can be extrapolated to the total population of São Paulo. The use of two $24 \mathrm{HR}$ allowed estimation of usual food intake but the period between assessment surveys (2003-2007) can be considered large, so one could argue that changes over time could lead to differential changes in eating patterns, as well as in within- and between-person variation. However, it is known that any adjustment gives less biased results than not adjusting distributions $^{(4,34,35)}$.

\section{Conclusion}

The excessive meat intake, associated with poorer diet quality observed, support initiatives and policies advising to reduce red and processed meat intake to within recommended amounts, as part of a healthy and environmentally sustainable diet.

\section{Acknowledgements}

Sources of funding: This research was supported by the Research Support Foundation of São Paulo, the National 
Council of Technological and Scientific Development and the Department of Health of São Paulo. Conflicts of interest: There are no conflicts of interest to declare. Authors' contributions: A.M.C. carried out the study and data analyses and drafted the manuscript. C.L.G.C. conceived of the study and participated in its design and coordination. R.M.F. participated in the design of the study and data analyses. D.M.L.M. conceived of the study, participated in its design and coordination and helped to draft the manuscript. All authors read and approved the final manuscript. Acknowledgements: The authors are grateful to the funding bodies for the financial support that enabled development of this study.

\section{References}

1. Ministério da Saúde, Secretaria de Atenção à Saúde, Coordenação-Geral da Política de Alimentação e Nutrição (2006) Guia Alimentar para a População Brasileira: Promovendo a Alimentação Saudável. Brasília: Ministério da Saúde.

2. McAfee AJ, McSorley EM, Cuskelly GJ et al. (2010) Red meat consumption: an overview of the risks and benefits. Meat Sci 84, 1-13.

3. World Cancer Research Fund \& American Institute for Cancer Research (2007) Food, Nutrition, Physical Activity, and the Prevention of Cancer: A Global Perspective. Washington, DC: AICR.

4. Daniel CR, Cross AJ, Koebnick C et al. (2011) Trends in meat consumption in the USA. Public Health Nutr 14, 575-583.

5. Micha R, Wallace SK \& Mozaffarian D (2010) Red and processed meat consumption and risk of incident coronary heart disease, stroke, and diabetes mellitus: a systematic review and meta-analysis. Circulation 121, 2271-2283.

6. Cosgrove M, Flynn A \& Kiely M (2005) Consumption of red meat, white meat and processed meat in Irish adults in relation to dietary quality. Br J Nutr $\mathbf{9 3}, 933-942$.

7. Hodgson JM, Ward NC, Burke V et al. (2007) Increased lean red meat intake does not elevate markers of oxidative stress and inflammation in humans. J Nutr 137, 294-303.

8. Vergnaud AC, Norat T, Romaguera D et al. (2010) Meat consumption and prospective weight change in participants of the EPIC-PANACEA study. Am J Clin Nutr 92, 398-407.

9. Okubo H, Sasaki S, Murakami K et al. (2011) The ratio of fish to meat in the diet is positively associated with favorable intake of food groups and nutrients among young Japanese women. Nutr Res 31, 169-177.

10. Steinfeld H, Gerber P, Wassenaar T et al. (2006) Livestock's Long Shadow: Environmental Issues and Options. Rome: FAO.

11. Ministério da Ciência e Tecnologia (2009) Inventário Brasileiro das Emissões e Remoções Antrópicas de Gases de Efeito Estufa. Informações Gerais e Valores Preliminare. http://www.mct.gov.br/upd_blob/0207/207624.pdf (accessed August 2011)

12. Inquéritos de Saúde (2005) Inquérito de Saúde no Município de São Paulo. ISA-Capital 2003. http://hygeia. fsp.usp.br/isa-sp/index_arquivos/Page3157.htm (accessed August 2011).

13. Castro MA, Barros RR, Bueno MB et al. (2009) Trans fatty acids intake among the population of the city of São Paulo, Brazil. Rev Saude Publica 43, 991-997.
14. Thompson FE \& Byers $\mathrm{T}$ (1994) Dietary assessment resource manual. J Nutr 124, 11 Suppl., 2245S-2317S.

15. Pinheiro ABV, de Lacerda EM A, Benzecry EH et al. (2000) Tabela para Avaliação de Consumo Alimentar em Medidas Caseiras, 4th ed. São Paulo: Atheneu.

16. Fisberg RM \& Villar BS (2002) Manual de Receitas e Medidas Caseiras para Cálculo de Inquéritos Alimentares: Manual Elaborado para Auxiliar o Processamento de Inquéritos Alimentares. São Paulo: Signus.

17. Haubrock J, Nöthlings U, Volatier JL et al. (2011) Estimating usual food intake distributions by using the multiple source method in the EPIC-Potsdam Calibration Study. J Nutr 141, 914-920.

18. Harttig U, Haubrock J, Knüppel S et al. (2011) The MSM program: web-based statistics package for estimating usual dietary intake using the Multiple Source Method. Eur J Clin Nutr 65, Suppl. 1, S87-S91.

19. Fisberg RM, Morimoto JM, Slater B et al. (2006) Dietary quality and associated factors among adults living in the state of São Paulo, Brazil. J Am Diet Assoc 106, 2067-2072.

20. Previdelli AN, Lipi M, Castro ML et al. (2010) Dietary quality and associated factors among factory workers in the Metropolitan Region of São Paulo, Brazil. J Am Diet Assoc 110, 786-790.

21. Previdelli AN, Andrade SC, Pires MM et al. (2011) Índice de Qualidade da Dieta Revisado (IQD-R): desenvolvimento para população brasileira. Rev Saude Publica 45, 794-798.

22. Guenther PM, Reedy J, Krebs-Smith SM et al. (2007) Development and Evaluation of the Healthy Eating Index-2005: Technical Report. Alexandria, VA: Center for Nutrition Policy and Promotion, US Department of Agriculture; available at http://www.cnpp.usda.gov/ HealthyEatingIndex.htm

23. Fundação Seade (2008) Anuário Estatístico do Estado de São Paulo 2003. http://www.seade.gov.br/produtos/ anuario/mostra_tabela.php?anos $=2003 \&$ tema $=$ dem\&tabpesq $=$ dem2003_02\&tabela=null (accessed August 2011).

24. Cedeberg C, Persson UM, Neovius K et al. (2011) Including carbon emissions from deforestation in the carbon footprint of Brazilian beef. Environ Sci Technol 45, 1773-1779.

25. Rizzo L, Moser RP, Waldron W et al. (2008) Analytic Methods to Examine Changes Across Years Using HINTS 2003 and 2005 Data. NIH Publication no. 08-6435. Bethesda, MD: US Department of Health and Human Services, National Institutes of Health and Division of Cancer Control and Population Sciences, National Cancer Institute.

26. Instituto Brasileiro de Geografia e Estatística (2010) Indicadores IBGE: Pesquisa de Orçamentos Familiares 2008-2009: Antropometria e Estado Nutricional de Crianças, Adolescentes e Adultos no Brasil. Rio de Janeiro: IBGE.

27. Instituto Brasileiro de Geografia e Estatística (2006) Indicadores IBGE: Pesquisa de Orçamentos Familiares 2002-2003: Antropometria e Estado Nutricional de Crianças, Adolescentes e Adultos no Brasil. Rio de Janeiro: IBGE.

28. McMichael A, Powles JW, Butler CD et al. (2007) Food, livestock production, energy, climate change, and health. Lancet 370, 1253-1263.

29. Secretaria Municipal do Verde e do Meio Ambiente (2005) Inventário de Emissão de Gases de Efeito Estufa do Município de São Paulo. http://ww2.prefeitura.sp.gov.br/ arquivos/secretarias/meio_ambiente/Sintesedoinventario.pdf (accessed August 2011).

30. Carlsson-Kanyama A \& González AD (2009) Potencial contributions of food consumption patterns to climate change. Am J Clin Nutr 89, issue 5, 1704S-1709S. 
31. Bigio RS, Verly Junior E, Castro MA et al. (2011) Determinants of fruit and vegetable intake in adolescents using quantile regression. Rev Saude Publica 45, 448-456.

32. Bazzano LA (2005) Dietary Intake of Fruit and Vegetable and Risk of Diabetes Mellitus and Cardiovascular Diseases. Geneva: WHO.

33. Swatland HJ (2010) Meat products and consumption culture in the West. Meat Sci $\mathbf{8 6}, 80-85$.
34. Beaton GH, Milner J, Corey P et al. (1979) Sources of variance in 24-hour dietary recall data: implications for nutrition study design and interpretation. Am J Clin Nutr 32, 2546-2559.

35. Jahns L, Arab L, Carriquiry A et al. (2005) The use of external within-person variance estimates to adjust nutrient intake distributions over time and across populations. Public Health Nutr 8, 69-76. 